\title{
Autosomal dominant (AD) pure spastic paraplegia (HSP) linked to locus SPG4 affects almost exclusively males in a large pedigree
}

\author{
A Starling, P Rocco, M R Passos-Bueno, J Hazan, S K Marie, M Zatz
}

J Med Genet 2002;39:e77(http://www.jmedgenet.com/cgi/content/full/39/12/e77)

$\mathrm{H}$ ereditary spastic paraplegia (HSP) includes a heterogeneous group of degenerative disorders of the central motor system characterised by progressive spasticity of the lower limbs. The inheritance may be autosomal dominant $(\mathrm{AD})$, autosomal recessive (AR), or X linked.

Clinically, two forms of HSP can be distinguished: a pure form, with leg spasticity and weakness, and a complicated form, with other manifestations such as optic neuropathy, retinopathy, movement disorders, dementia, epilepsy, ataxia, ichthyosis, mental retardation, and deafness. Both complicated and pure forms are genetically heterogeneous. Although $\mathrm{X}$ linked forms have been reported, ${ }^{12}$ pure HSP usually displays $\mathrm{AD}$ inheritance. The major neuropathological finding in the latter form is axonal degeneration involving the terminal ends of the longest fibres of the corticospinal tracts and dorsal columns. ${ }^{34}$

AD-HSP is the most common form of the disease, accounting for approximately $70-80 \%$ of the families. Seven AD loci have been mapped to date: SPG3 on chromosome 14q11.2$\mathrm{q} 24.3,{ }^{56}$ SPG4 on chromosome $2 \mathrm{p},{ }^{78}$ SPG6 on chromosome 15q11.1, ${ }^{9}$ SPG8 on chromosome 8q23-q24, ${ }^{10-13}$ SPG10 on chromosome $12 \mathrm{ql}^{1,},{ }^{14}$ and more recently two novel loci were mapped on chromosome 2q24-q34 $4^{15}$ and chromosome 19q13. ${ }^{16}$ SPG4 is the most common form, accounting for about $40 \%$ of all AD-HSP families. ${ }^{17}{ }^{18}$ The protein encoded by SPG4, spastin, ${ }^{19}$ and more recently by SPG3, a GTPAse (SPG3A), ${ }^{20}$ has just been identified but the gene product of the other AD-HSP forms is still unknown.

Here we report a large three generation family referred to us with a diagnosis of pure spastic paraplegia. Pedigree analysis showed the existence of 24 clinically affected males but only one clinically affected female. However, $\mathrm{X}$ linked inheritance was ruled out since there were several instances of male to male transmission. Linkage analysis showed that the disease gene is linked to the SPG4 locus (lod score $=8.29, \theta=0$ ). Screening of mutations in the spastin gene showed no mutation in the coding region, suggesting the possibility of a novel mutation or the existence of another gene in close proximity.

\section{SUBJECTS AND METHODS}

This family was referred to us at the Centro de Estudos do Genoma Humano (Human Genome Research Center), at the Departamento de Biologia, Universidade de São Paulo, with a diagnosis of "pure" spastic paraplegia. The proband, a 50 year old male (III.6), reported that he had 23 male relatives affected by the same condition, which suggested $\mathrm{X}$ linked recessive inheritance. However, pedigree analysis (fig 1 ) indicated that his father and grandfather were also affected and that there were several other instances of male to male transmission, thus confirming an AD pattern of inheritance. The family members were submitted to a careful clinical and neurological evaluation and all of them were re-examined after a period varying from two to five years (table 1). Six other

\section{Key points}

- Linkage analysis showed that a large family with an autosomal dominant form of pure spastic paraplegia was linked to the SPG4 locus (maximum two point lod score $8.29, \theta=0$ ) where the spastin gene is localised.

- Screening of the entire coding region of the spastin gene did not show any mutation, suggesting either that there is another AD-HSP gene in this region or the existence of a novel mutation in the non-coding regions

- In the present family, the condition affects almost exclusively males (24 men and one woman clinically affected) although the inheritance is undoubtedly autosomal dominant (confirmed by several male to male transmissions)

affected members (III.12, III.14, III.19, III.22, III.23, III.24) were examined by another neurologist. Based on clinical and neurological examination, patients were classified into four groups: (1) definitely not affected, (2) asymptomatic but with one abnormality on neurological examination, (3) possibly affected with two or more abnormalities on neurological examination, and (4) definitely affected with abnormal gait and neurological examination. Subjects who were dead were diagnosed as "affected " or "unaffected" based on relatives' information.

After informed consent, DNA was extracted from blood, as described elsewhere. ${ }^{21}$ Linkage analysis was performed based on 25 clinically affected subjects, four asymptomatic mothers of affected sons, 42 unaffected subjects, and five normal spouses. We considered to be "affected" those with clinical or abnormal neurological signs as well as asymptomatic "transmitting" mothers who were classified by pedigree analysis (that is, the daughters of "affected" subjects who had symptomatic sons).

Two point lod scores between HSP and SPG4 markers were calculated by the MLINK and LINKAGE package (version 5.0) under the assumption of an autosomal dominant gene with a frequency of $10^{-4}$, equal female and male recombination rates, and penetrance of $90 \%$. Allele frequencies were assumed to be equal for all markers.

The 17 exons of the spastin gene (and all their flanking intronic boundaries) were screened for mutations by use of SSCP (single strand conformation polymorphism) analysis. A bi-directional sequencing of all PCR products including part of the promoter region of the spastin gene was carried out in an ABI 377 automated DNA sequencer. The Dye Deoxy Terminator Cycle Sequencing Ready Reaction Kit (Perkin Elmer) was used and the reaction was performed according to the ABI standard protocol, after purification of $100 \mathrm{ng}$ of the PCR 


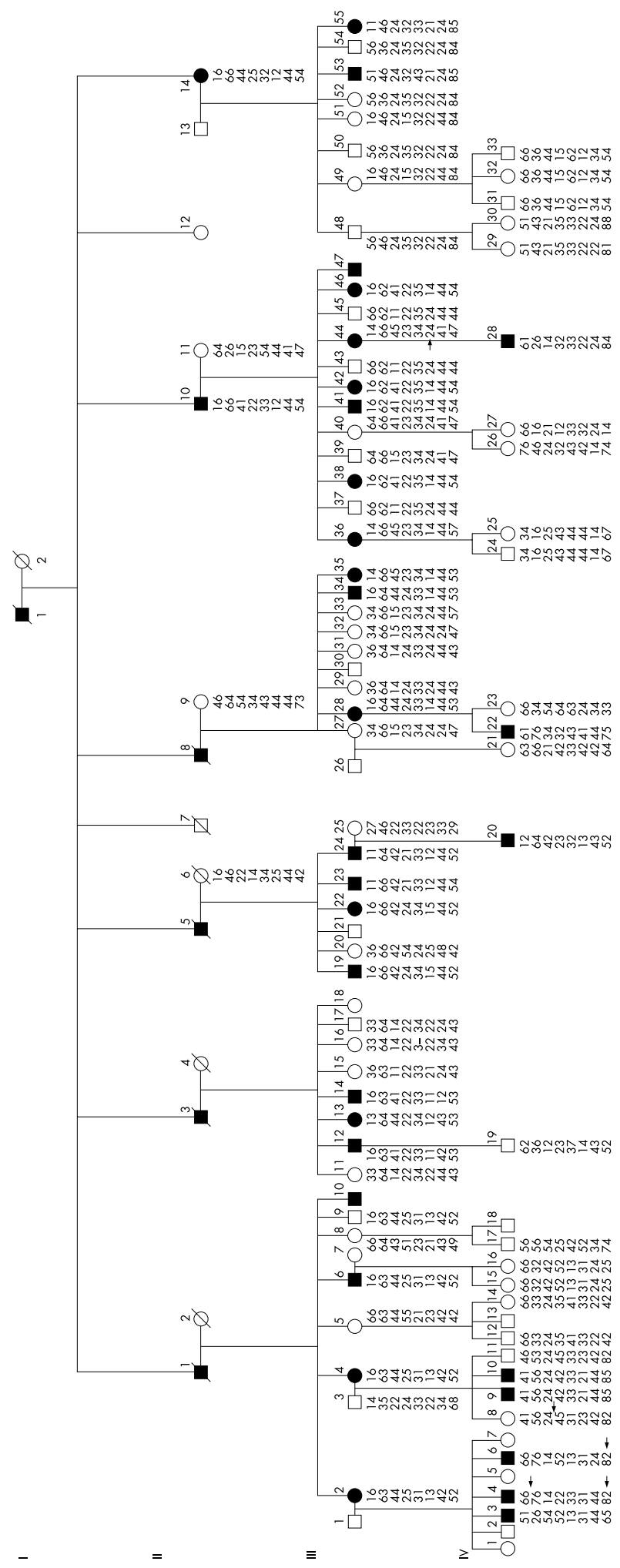

Figure 1 Haplotype analysis in the family with autosomal dominant pure spastic paraplegia. Arrows indicate the recombination events between markers.

products with exonuclease I and shrimp alkaline phosphatase. The same primers were used for PCR amplification and sequencing.

For RT-PCR, $15 \mathrm{ml}$ of EDTA anticoagulated blood were centrifuged at $1000 \mathrm{~g}$ for 10 minutes. Cells from the buffy coat were washed once in phosphate buffered saline and total RNA was extracted using TRIZOL (Gibco BRL).

\section{RESULTS}

Linkage analysis with markers of chromosomes $14 \mathrm{q}$ and $15 \mathrm{q}$ first excluded loci SPG3 and SPG6, respectively (data not shown). A total of eight microsatellite markers from the SPG4 region (D2S2383, D2S2255, D2S2283, D2S352, D2S2203, D2S2351, D2S2347, D2S367) were then tested. Positive lod scores were found with markers D2S352 and D2S2203 from the SPG4 locus (table 2). The haplotypes observed with these eight markers are shown in fig 1 . The order of the markers is consistent with the physical map of the region. ${ }^{22}$ Recombination events were observed for III.44, IV.4, IV.6, and IV.8.

In an attempt to identify the disease causing mutation, the 17 exons of the spastin gene were screened by sequencing but no mutation could be identified.

A total of 74 family members were clinically examined, 65 personally by one of us (table 1 ). None of them had any additional neurological abnormality, thus confirming the diagnosis of "pure" spastic paraplegia. All spouses were asymptomatic and had a normal neurological examination. With the exception of one affected man (IV.9) who was more severely affected at the age of 33, all others showed a mild course with onset ranging from 20 to 40 years old. None of them was confined to a wheelchair.

In this family there was a total of 47 men and 45 women, which did not differ from the expected 1:1 ratio. Among 34 men who underwent clinical examination and had their DNA analysed, the proportion of those who had inherited the "at risk" haplotype did not differ from expected (18 of 34, $\mathrm{p}>0.05$ ). However, among 40 women who were clinically examined and who had their DNA analysed, this proportion was significantly less than expected ( 13 of $40, \chi^{2}=4.9$, $\mathrm{p}<0.05$ ). Also a gender difference in clinical manifestation was observed. Among the 13 women who carried the "at risk" haplotype, 10 showed some abnormality on neurological examination but only one showed symptoms typical of pure HSP, whereas $100 \%$ of the men with the disease haplotype and who were older than 35 were clinically affected.

\section{DISCUSSION}

The present family is probably the largest one with autosomal dominant spastic paraplegia reported to date. The SPG4 gene has 17 exons, spans a physical distance of $\sim 90 \mathrm{~kb}$, and encodes the spastin protein. ${ }^{19}$ At least 59 different mutations in the spastin gene, scattered throughout the coding region, have been identified..$^{17}{ }^{23} 24$ No apparent correlation between the type of mutation (missense versus truncating) and severity of the phenotype was observed. In addition, both pure and complicated forms of AD-HSP may be caused by SPG4 mutations.

Haploinsufficiency as the physiopathological mechanism has been proposed ${ }^{192} 25$ with the abnormal phenotype being caused by a $50 \%$ reduction in spastin level. According to these authors, relatively small differences in the level of wild type spastin expression might have important clinical consequences accounting for the highly variable course. Interestingly, however, a homozygous missense mutation associated with a mild phenotype has also been reported. ${ }^{18}{ }^{23}$

In the present family, although the lod score of 8.29 with marker D2S352 indicates linkage to the SPG4 locus, screening of the entire coding region of the spastin gene in affected members did not show any mutation. This might be explained either by a novel mutation in the non-coding region, such as a mutation in the promoter region, or the appearance of a new splice site in an intron, or by the presence of another gene closely linked to the spastin gene. Indeed, Higgins $e t a l^{26}$ have just found an atypical intronic deletion in the SPG4 gene that causes this form of AD-HSP. On the other hand, the existence of closely linked genes causing similar disorders has been 
Table 1 Summary of neurological examination (without taking into consideration DNA analysis)

\begin{tabular}{|c|c|c|c|c|c|c|c|c|}
\hline & Subject & Sex & Age & Spasticity & Hypereflexia & Babinski & Clonus & Classification \\
\hline 1 & II. 10 & $M$ & 80 & $Y$ & $Y$ & $Y$ & $Y$ & 4 \\
\hline 2 & III. 2 & $\mathrm{~F}$ & 55 & $\mathrm{~N}$ & $Y$ & $\mathrm{~N}$ & $\mathrm{~N}$ & 2 \\
\hline 3 & III. 4 & $\mathrm{~F}$ & 54 & Y & $Y$ & $Y$ & $N$ & 4 \\
\hline 4 & III.5 & $\mathrm{F}$ & 56 & $\mathrm{~N}$ & $\mathrm{~N}$ & $\mathrm{~N}$ & $\mathrm{~N}$ & 1 \\
\hline 5 & III.6 & $M$ & 50 & $Y$ & $Y$ & $Y$ & $Y$ & 4 \\
\hline 6 & III. 8 & $\mathrm{~F}$ & 47 & $N$ & $N$ & $\mathrm{~N}$ & $\mathrm{~N}$ & 1 \\
\hline 7 & 111.9 & $M$ & 44 & $Y$ & $Y$ & $Y$ & $\mathrm{~N}$ & 4 \\
\hline 8 & III. 13 & $\mathrm{~F}$ & 52 & $\mathrm{~N}$ & $Y$ & $\mathrm{~N}$ & $\mathrm{~N}$ & 2 \\
\hline 9 & III. 15 & $\mathrm{~F}$ & 48 & $N$ & $\mathrm{~N}$ & $\mathrm{~N}$ & $\mathrm{~N}$ & 1 \\
\hline 10 & III. 16 & $\mathrm{~F}$ & 45 & $\mathrm{~N}$ & $N$ & $\mathrm{~N}$ & $\mathrm{~N}$ & 1 \\
\hline 11 & III. 27 & $\mathrm{~F}$ & 53 & $\mathrm{~N}$ & $\mathrm{~N}$ & $\mathrm{~N}$ & $\mathrm{~N}$ & 1 \\
\hline 12 & III. 28 & $\mathrm{~F}$ & 49 & $\mathrm{~N}$ & $\mathrm{~N}$ & $\mathrm{~N}$ & $\mathrm{~N}$ & 1 \\
\hline 13 & III.29 & $\mathrm{F}$ & 47 & $N$ & $N$ & $\mathrm{~N}$ & $\mathrm{~N}$ & 1 \\
\hline 14 & III.31 & $\mathrm{F}$ & 45 & $\mathrm{~N}$ & $\mathrm{~N}$ & $\mathrm{~N}$ & $\mathrm{~N}$ & 1 \\
\hline 15 & III.32 & $\mathrm{F}$ & 40 & $\mathrm{~N}$ & $\mathrm{~N}$ & $\mathrm{~N}$ & $\mathrm{~N}$ & 1 \\
\hline 16 & III.33 & $\mathrm{F}$ & 39 & $\mathrm{~N}$ & $N$ & $N$ & $N$ & 1 \\
\hline 17 & III.35 & $\mathrm{F}$ & 34 & $\mathrm{~N}$ & $Y$ & $Y$ & $Y$ & 3 \\
\hline 18 & III.36 & $\mathrm{F}$ & 50 & $\mathrm{~N}$ & $Y$ & $Y$ & $\mathrm{~N}$ & 2 \\
\hline 19 & III.38 & $\mathrm{F}$ & 53 & $\mathrm{~N}$ & $\mathrm{~N}$ & $\mathrm{~N}$ & $\mathrm{~N}$ & 1 \\
\hline 20 & III.39 & $M$ & 49 & $\mathrm{~N}$ & $\mathrm{~N}$ & $\mathrm{~N}$ & $\mathrm{~N}$ & 1 \\
\hline 21 & III. 40 & $\mathrm{~F}$ & 51 & $\mathrm{~N}$ & $\mathrm{~N}$ & $\mathrm{~N}$ & $\mathrm{~N}$ & 1 \\
\hline 22 & III.41 & $M$ & 46 & $Y$ & $Y$ & $Y$ & $Y$ & 4 \\
\hline 23 & III. 42 & $\mathrm{~F}$ & 47 & $N$ & $Y$ & $\mathrm{~N}$ & $N$ & 2 \\
\hline 24 & III. 43 & $M$ & 43 & $\mathrm{~N}$ & $\mathrm{~N}$ & $\mathrm{~N}$ & $\mathrm{~N}$ & 1 \\
\hline 25 & III. 44 & $\mathrm{~F}$ & 42 & $\mathrm{~N}$ & $Y$ & $\mathrm{~N}$ & $\mathrm{~N}$ & 2 \\
\hline 26 & III. 45 & $M$ & 41 & $\mathrm{~N}$ & $\mathrm{~N}$ & $\mathrm{~N}$ & $\mathrm{~N}$ & 1 \\
\hline 27 & III. 46 & $\mathrm{~F}$ & 43 & $\mathrm{~N}$ & $Y$ & $Y$ & $Y$ & 3 \\
\hline 28 & III. 47 & $M$ & 34 & $Y$ & $Y$ & $Y$ & $Y$ & 4 \\
\hline 29 & III. 48 & $M$ & 53 & $N$ & $N$ & $\mathrm{~N}$ & $N$ & 1 \\
\hline 30 & III.51 & $\mathrm{F}$ & 46 & $\mathrm{~N}$ & $\mathrm{~N}$ & $\mathrm{~N}$ & $\mathrm{~N}$ & 1 \\
\hline 31 & III.52 & $\mathrm{F}$ & 44 & $\mathrm{~N}$ & $Y$ & $\mathrm{~N}$ & $\mathrm{~N}$ & 2 \\
\hline 32 & III.53 & $M$ & 41 & $N$ & $Y$ & $\mathrm{~N}$ & $N$ & 2 \\
\hline 33 & III.54 & $M$ & 40 & $\mathrm{~N}$ & $\mathrm{~N}$ & $\mathrm{~N}$ & $\mathrm{~N}$ & 1 \\
\hline 34 & III. 55 & $\mathrm{~F}$ & 33 & $\mathrm{~N}$ & $Y$ & $\mathrm{~N}$ & $\mathrm{~N}$ & 2 \\
\hline 35 & IV. 3 & $M$ & 31 & $Y$ & $Y$ & $Y$ & $Y$ & 4 \\
\hline 36 & IV. 4 & $M$ & 30 & $Y$ & $Y$ & $Y$ & $Y$ & 4 \\
\hline 37 & IV.6 & $M$ & 25 & $\mathrm{~N}$ & $Y$ & $Y$ & $N$ & 3 \\
\hline 38 & IV. 8 & $\mathrm{~F}$ & 36 & $N$ & $\mathrm{~N}$ & $\mathrm{~N}$ & $\mathrm{~N}$ & 1 \\
\hline 39 & IV.9 & $M$ & 34 & $Y$ & $Y$ & $Y$ & $Y$ & 4 \\
\hline 40 & IV. 10 & $M$ & 31 & $Y$ & $Y$ & $Y$ & $Y$ & 4 \\
\hline 41 & IV. 12 & $M$ & 23 & $N$ & $N$ & $\mathrm{~N}$ & $N$ & 1 \\
\hline 42 & IV. 14 & $\mathrm{~F}$ & 29 & $\mathrm{~N}$ & $N$ & $\mathrm{~N}$ & $\mathrm{~N}$ & 1 \\
\hline 43 & IV. 15 & $\mathrm{~F}$ & 18 & $\mathrm{~N}$ & $\mathrm{~N}$ & $\mathrm{~N}$ & $\mathrm{~N}$ & 1 \\
\hline 44 & IV. 16 & $\mathrm{~F}$ & 14 & $\mathrm{~N}$ & $\mathrm{~N}$ & $\mathrm{~N}$ & $\mathrm{~N}$ & 1 \\
\hline 45 & IV. 18 & $M$ & 10 & $N$ & $N$ & $\mathrm{~N}$ & $N$ & 1 \\
\hline 46 & IV. 19 & $M$ & 16 & $\mathrm{~N}$ & $\mathrm{~N}$ & $\mathrm{~N}$ & $\mathrm{~N}$ & 1 \\
\hline 47 & IV.20 & $M$ & 23 & $Y$ & $Y$ & $Y$ & $Y$ & 1 \\
\hline 48 & IV. 23 & $\mathrm{~F}$ & 25 & $N$ & $N$ & $\mathrm{~N}$ & $\mathrm{~N}$ & 1 \\
\hline 49 & IV. 25 & $M$ & 22 & $\mathrm{~N}$ & $\mathrm{~N}$ & $\mathrm{~N}$ & $\mathrm{~N}$ & 1 \\
\hline 50 & IV.26 & $\mathrm{F}$ & 16 & $\mathrm{~N}$ & $\mathrm{~N}$ & $\mathrm{~N}$ & $\mathrm{~N}$ & 1 \\
\hline 51 & IV. 27 & $\mathrm{~F}$ & 28 & $N$ & $N$ & $\mathrm{~N}$ & $\mathrm{~N}$ & 1 \\
\hline 52 & IV.28 & $M$ & 21 & $\mathrm{~N}$ & $Y$ & $\mathrm{~N}$ & $\mathrm{~N}$ & 2 \\
\hline 53 & IV.29 & $\mathrm{F}$ & 32 & $\mathrm{~N}$ & $\mathrm{~N}$ & $\mathrm{~N}$ & $\mathrm{~N}$ & 1 \\
\hline 54 & IV.30 & $\mathrm{F}$ & 28 & $\mathrm{~N}$ & $\mathrm{~N}$ & $\mathrm{~N}$ & $\mathrm{~N}$ & 1 \\
\hline 55 & IV.31 & $M$ & 31 & $\mathrm{~N}$ & $N$ & $\mathrm{~N}$ & $\mathrm{~N}$ & 1 \\
\hline 56 & IV.32 & $\mathrm{F}$ & 26 & $\mathrm{~N}$ & $\mathrm{~N}$ & $\mathrm{~N}$ & $\mathrm{~N}$ & 1 \\
\hline 57 & IV.33 & $M$ & 23 & $\mathrm{~N}$ & $N$ & $\mathrm{~N}$ & $N$ & 1 \\
\hline
\end{tabular}

found for other diseases, such as autosomal recessive limb-girdle muscular dystrophy ( $\alpha$ sarcoglycanopathy and telethoninopathy at $17 \mathrm{q}^{27}$ ) and more recently for $\mathrm{X}$ linked spastic paraplegia. ${ }^{12}$

The intrafamilial variability in the severity of the clinical course observed in the present family was also found in other published SPG4 families. ${ }^{1732528}$ Clinical anticipation has also been reported for some families, ${ }^{29}$ but no evidence for long CAG/CTG repeats in families linked to the SPG4 locus was found in another study. ${ }^{2230}$ In our family, although the most severely affected subject belonged to the last generation, it was not possible to determine if there was clinical anticipation since most affected subjects did not recall when they noticed the first symptoms.

However, the most intriguing finding in the present family, which has apparently not been reported for other published AD HSP families, was the gender difference in clinical manifestation. This difference is so striking that, with the exception of one mildly affected female, the disease is limited to males. Interestingly, Byrne et $a l^{31}$ have just reported an Irish family linked to the SPG4 locus with four clinically affected males, but where four among five asymptomatic members carrying the at risk haplotype were women. An excess of affected men has been reported for other autosomal 
Table 2 Lod score values with markers from the SPG4 locus

\begin{tabular}{llllllll}
\hline \multirow{2}{*}{ Marker } & \multicolumn{2}{l}{ Lod score at $\theta=$} \\
\cline { 2 - 8 } & 0 & 0.01 & 0.05 & 0.10 & 0.20 & 0.30 & 0.40 \\
\hline D2S2383 & -10.89 & -10.64 & -9.61 & -8.9 & -6.43 & -3.3 & -2.79 \\
D2S2255 & 2.85 & 2.82 & 2.68 & 2.47 & 1.94 & 1.34 & 0.69 \\
D2S2283 & 6.52 & 6.41 & 6.34 & 5.89 & 4.64 & 3.17 & 1.53 \\
D2S352 & $\mathbf{8 . 2 9}$ & 8.14 & 7.54 & 6.78 & 5.22 & 3.54 & 1.72 \\
D2S2203 & 6.45 & 6.36 & 5.95 & 5.40 & 4.19 & 2.85 & 1.37 \\
D2S2351 & -8.09 & -3.18 & -1.31 & -0.38 & 0.39 & 0.57 & 0.41 \\
D2S2347 & -8.09 & -3.18 & -1.31 & -0.38 & 0.39 & 0.57 & 0.41 \\
D2S367 & -10.89 & -10.64 & -9.61 & -8.9 & -6.43 & -3.3 & -2.79 \\
\hline
\end{tabular}

dominant neurological disorders such as myotonic dystrophy, ${ }^{323}$ Machado-Joseph disease or SCA3 cerebellar ataxia, ${ }^{34}$ DRPLA, ${ }^{35}$ and more recently facioscapulohumeral muscular dystrophy (FSHMD) ${ }^{36}$ For SCA3, myotonic dystrophy, and DRPLA it has been suggested that the excess of affected males could be explained by meiotic drive favouring the transmission of enlarged alleles. However, in the case of FSHMD, DNA analysis showed that the proportion of men and women carrying the deleted abnormal EcoRI/BlnI allele was the same, thus suggesting other mechanisms to explain why women were less often or more mildly affected than men.

In this kindred, there was a total of 47 men and 45 women, which did not differ from the expected 1:1 ratio. Therefore, the gender difference in the proportion of affected males versus females could not be explained by chance ascertainment of a family with an excess of males.

The observation of a significantly greater proportion of men than women who inherited the "at risk" haplotype suggests meiotic drive, that is, preferential transmission of the normal allele to females or a selection against sperm carrying the $\mathrm{X}$ chromosome together with the abnormal HSP allele. In addition, with the exception of one case (III.4), women carrying the "at risk" allele were not clinically affected. Thus, the lack of affected females in the present family would be explained by a significantly smaller proportion of those carrying the "at risk" allele and additionally by the fact that those who carried it were protected against the deleterious effect of the pathogenic gene.

It is important to point out that this gender difference cannot be explained by age dependent penetrance, since on average women were five years older than men at examination (the mean age for women was 40 (SD 4.5) years old and the mean age for men was 35 (SD 5.0) years old).

Meiotic drive was described for Drosophila long ago and more recently a segregation distorter locus coding for a truncated RanGAP (a nuclear transport protein) has been reported to explain this phenotype. ${ }^{37}$ According to these authors, defective RanGAP encoded by the $S d$ gene would interfere with nuclear transport in spermatids carrying a sensitive responder gene.

With the exception of the present family and the family recently reported by Byrne et al, ${ }^{31}$ the fact that a gender difference in the phenotypic expression has not been reported for other pure AD HSP families is intriguing. However, an explanation could be if a putative distorter locus were segregating only in some families. If such a distorter locus selected against spermatids carrying the $\mathrm{X}$ chromosome together with the SPG4 disease locus, it would explain the smaller proportion of women carrying the "at risk" haplotype but not the significantly higher proportion of non-penetrant women.

On the other hand, a partially penetrant mutation in the spastin gene was reported by Svenson et al. ${ }^{24}$ The mutant allele produced both mutant and full length transcript. If the production of the normal or the abnormal transcript were gender dependent, it might provide an explanation for the sex difference observed in the present family.

It has been also suggested that retrotransposons could be mediators of phenotypic variation in mammals producing phenotypic variation even between genetically identical subjects. ${ }^{38}$

Understanding the mechanisms to explain the gender difference observed in the present family as well as why some subjects are protected from the clinical manifestation of pathological mutations will be of utmost importance for future therapeutic approaches.

\section{ACKNOWLEDGEMENTS}

The collaboration of the following persons is gratefully acknowledged: Dr Rita de Cassia Pavanello, Eloísa de Sá Moreira, Antônia Cerqueira, Marta Canovas, and Constância Urbani from the Brazilian Human Genome Research Center and Mavel and Nuria Fonknechten from Genoscope, France. This work was supported by FAPESP-CEPID, PRONEX, and CNPq.

\section{Authors' affiliations}

A Starling, P Rocco, M R Passos-Bueno, M Zatz, Centro de Estudos do Genoma Humano, Departamento de Biologia, Instituto de Biociências, Universidade de São Paulo, São Paulo, Brazil

J Hazan, Genoscope, CNS, 2 rue Gaston Cremieux, 91000 Evry, France

S K Marie, Departamento de Neurologia, Faculdade de Medicina, Universidade de São Paulo, São Paulo, Brazil

Correspondence to: Professor M Zatz, Departamento de Biologia, IB-USP, Universidade de São Paulo, Rua do Matão 277/Sala 211 , São Paulo, SP, Brazil; mayazatz@usp.br

\section{REFERENCES}

1 Cambi F, Tartaglino L, Lublin FD, McCarren D. X-linked pure familial spastic paraparesis: characterization of a large kindred with magnetic resonance imaging studies. Arch Neurol 1995;52:665-9.

2 Starling A, Rocco P, Cambi F, Hobson G, Passos-Bueno MR, Zatz M. Further evidence for a fourth gene causing $X$-linked pure spastic paraplegia. Am J Med Genet 2002;11 1:152-6.

3 Fink JK, Heiman-Patterson T, Bird T, Cambi F, Dube MP, Figlevicz DA Siddique T. Hereditary spastic paraplegia: advances in genetic research. Neurology 1996;46:1508-1 1

4 Reid E. Pure hereditary spastic paraplegia. J Med Genet 1997;34:499-503

5 Hazan J, Lammy C, Melki J, Munnich A, de Recondo J, Weissenbach J. Autosomal dominant familial spastic paraplegia is genetically heterogenous and one locus maps to chromosome 14q. Nat Genet 1993;5: 163-7

6 Gispert S, Santos N, Damen R, Voit T, Schulz J, Klockgether T, Orozco G, Kreuz F, Weissenbach J, Auburger G. Autosomal dominant familial spastic paraplegia: reduction of the FSPl candidate region on chromosome $14 \mathrm{q}$ to $7 \mathrm{cM}$ and locus heterogeneity. Am J Hum Genet 1995;56:183-7

7 Hazan J, Fontaine B, Bruyn RPM, Larry C, van Deutekom JC, Rime CS, Duirr A, Melki J, Lyon-Caen O, Agid Y. Linkage of a new locus for autosomal dominant familial spastic paraplegia to chromosome $2 \mathrm{p}$. Hum Mol Genet 1994;3:1569-73

8 Hentati A, Pericak-Vance MA, Lennon F, Wasserman B, Hentati F, Juneja T, Angrist MH, Hung WY, Boustany RM, Bohlega $S$. Linkage of a locus for autosomal dominant familial spastic paraplegia to chromosome $2 p$ markers. Hum Mol Genet 1994;3:1867-71. 
9 Fink JK, Wu CB, Jones SM, Sharp GB, Lange BM, Lesicki A, Reinglass T, Varvil T, Otterud B, Leppert M. Autosomal dominant familial spastic paraplegia: tight linkage to chromosome 15q. Am J Hum Genet 1995;56:188-92

10 Hedera P, Rainier S, Alvarado D, Zhao X, Williamson J, Otterud B, Leppert $M$, Fink JK. Novel locus for autosomal dominant hereditary spastic paraplegia, on chromosome 8q. Am J Hum Genet 1999;64:563-9.

11 Hedera P, DiMauro S, Bonilla E, Wald J, Eldevik OP, Fink JK. Phenotypic analysis of autosomal dominant hereditary spastic paraplegia linked to chromosome 8q. Neurology 1999;53:44-50.

12 Reid E, Dearlove AM, Whiteford ML, Rubinsztein C. Autosoma dominant spastic paraplegia: refined SPG8 locus and further genetic heterogeneity. Neurology 1999;53:1844-9.

13 Rocco PS, Vainzof M, Froehner SC, Marie SKN, Kunkel LM, Passos-Bueno MR, Zatz M. Autosomal dominant pure spastic paraplegia in a Brazilian family: linkage to chromosome $8 \mathrm{q}$ and study of muscle syntrophin b1. Am J Hum Genet 1999;64:A442.

14 Reid E, Dearlove AM, Rhodes M, Rubinsztein DC. A new locus for autosomal dominant "pure" hereditary spastic paraplegia mapping to chromosome 12q13, and evidence for further genetic heterogeneity. Am J Hum Genet 1999;65:757-63.

15 Fontaine B, Davoine CS, Dürr A, Paterntte C, Feki I, Weissenbach J, Hazan J, Brice A. A new locus for autosomal dominant pure spastic paraplegia on chromosome 2q24-q34. Am J Hum Genet 2000;66:702-7

16 Reid E, Dearlove AM, Osborn O, Rogers MT, Rubinsztein DC. A locus for autosomal dominant "pure" hereditary spastic paraplegia maps to chromosome 19q13. Am J Hum Genet 2000;66:728-32.

17 Fonknechten N, Mavel D, Byrne P, Davoine CS, Cruaud C, Boentsch D, Burgunder JM, Tartaglione A, Heinzlef O, Feki I, Deufel T, Parfrey N, Brice A, Fontaine B, Pru'homme JF, Weissenbach J, Dürr A, Hazan J. Spectrum of SPG4 mutations in autosomal dominant spastic paraplegia. Hum Mol Genet 2000:9:637-64.

18 Tallaksen C, Dürr A, Brice A. Recent advances in hereditary spastic paraplegia. Curr Opin Neurol 2001;14:457-63.

19 Hazan J, Fonknechten N, Mavel D, Partenotte C, Samson D, Artiguenave F, Davoine CS, Cruaud C, Dürr A, Wincker P, Brottier P, Cattolico L, Barbe V, Burgunder JM, Prud'homme JF, Brice A, Fontaine B, Heilig R, Weissenbach J. Spastin, a new AAA protein, is altered in the most frequent form of autosomal dominant spastic paraplegia. Nat Genet 1999;23:296-303

20 Zhao X, Alvarado D, Rainier S, Lemons R, Hedera P, Weber CH, Tukel T, Apak M, Heiman-Patterson T, Ming L, Bui M, Fink JK. Mutations in a newly identified GTPase gene cause autosomal dominant hereditary spastic paraplegia; Nat Genet 2001;29:326-31.

21 Miller AS, Dykes DD, Polesky HF. A simple salting out procedure for extracting DNA from human nucleated cells. Nucleic Acid Res $1988 ; 16: 1215$

22 Hazan J, Davoine CS, Mavel D, Fonknechten N, Paternotte C, Fizames C, Cruaud C, Samson D, Muselet D, Vega-Czarny N, Brice A, Gyapay $G$, Heilig R, Fontaine B, Weissenbach J. A fine integrated map of the SPG4 locus excludes an expanded CAG repeat in chromosome $2 \mathrm{p}$-linked autosomal dominant spastic paraplegia. Genomics 1999;15:309-19.

23 Lindsey JC, Lusher ME, McDermott CJ. White KD, Reid E, Rubinsztein DC, Bashir R, Hazan J, Shaw PJ, Bushby KMD. Mutation analysis of the spastin gene (SPG4) in patients with hereditary spastic paraparesis. J Med Genet 2000;37:759-65.
24 Svenson IK, Ashley-Koch AE, Gaskell PC, Riney TJ, Cumming WJK, Kingston HM, Hogan EL, Boustany RMN, Vance JM, Nance MA Pericak-Vance MA, Marchuk DA. Identification and expression analysis of spastin gene mutations in hereditary spastic paraplegia. Am J Hum Genet $2001 ; 68: 1077-85$

25 Burger J, Fonknechten N, Hoeltzenbein M, Neumann L, Bratanoff E, Hazan J, Reis A. Hereditary spastic paraplegia caused by mutations in He SPG4 gene. Eur J Hum Genet 2000;8:771-6.

26 Higgins JJ, Loveless JM, Goswami S, Nee LE, Cozzo C, De Biase A, Rosen DR. An atypical intronic deletion widens the spectrum of mutations in hereditary spastic paraplegia. Neurology 2001;56:1482-5.

27 Moreira ES, Wiltshire TJ, Faulkner G, Nilforoushan A, Vainzof M Suzuki OT, Valle G, Reeves R, Zatz M, Passos-Bueno MR, Jenne DE. Limb girdle muscular dystrophy type $2 G$ is caused by mutations in the gene encoding the sarcomeric protein telethonin. Nat Genet 2000;24:163-6.

28 Santorelli FM, Patrono C, Fortini D, Tessa A, Comanducci G, Bertini E, Pierallini A, Amabili GA, Casali C. Intrafamilial variability in hereditary spastic paraplegia associated with an SPG4 gene mutation. Neurology 2000;55:702-5.

29 Nielsen JE, Koefoed P, Abell K, Hasholt L, Eiberg H, Fenger K, Niebuhr E, Sorensen AS. CAG repeat expansion in autosomal dominant pure spastic paraplegia linked to chromosome. Hum Mol Genet 1997:6:1811-16.

30 Zander C, Yuan QP, Lindblad K, Stevanin G, Durr A, Davoine CS, Hazan J, Fontaine B, Brice A, Schalling M. No evidence for long CAG/CTG repeats in families with spastic paraplegia linked to chromosome. Neurosci Lett 2000;279:41-4

31 Byrne PC, McMonagle P, Webb S, Fitzgerald B, Parfrey NA, Hutchinson $M$. Age-related cognitive decline in hereditary spastic paraparesis linked to chromosome 2. Neurology 2001;54:1510-17.

32 Carey N, Johnson K, Nokelainen P, Peltonen L, Savontaus ML, Juvonen V, Anvret M, Grandell U, Chotai K, Robertson E, Middleton-Price H, Malcolm S. Meiotic drive at the myotonic dystrophy locus? Nat Genet 1994;6:117-18.

33 Zatz M, Passos-Bueno MR, Cerqueira A, Vainzof M. CTG repeat length in muscle from patients affected with myotonic dystrophy (DM). J Med Genet 1996:33:173.

34 lughetti P, Otto PA, Zatz M, Passos Bueno MR, Marie SK. Different behavior in the paternally vs maternally inherited mutated allele in Brazilian Machado-Joseph (MDD1) families. Am J Med Genet 1998:77:246-8.

35 Ikeuchi T, Igarashi S, Takiyama Y, Onodera O, Oyake M, Takano H, Koide R, Tanaka H, Tsuji S. Non-mendelian transmission in dentatorubral-pallidoluysian atrophy and Machado-Joseph disease: the mutant allele is preferentially transmitted in male meiosis. Am J Hum Genet 1996;58:730-3.

36 Zatz M, Marie SK, Cerqueira A, Vainzof M, Pavanello RC, Passos-Bueno MR. The facioscapulohumeral muscular dystrophy (FSHDI) gene affects males more severely and more frequently than females. Am J Med Genet 1998;77:155-61

37 Merrill C, Bayraktaroglu L, Kusano A, Ganetzky B. Truncated RanGAP encoded by the segregation distorter locus of Drosophila. Science 1999:283:1742-5.

38 Whitelaw E, Martin DIK. Retrotransposons as epigenetic mediators of phenotypic variation in mammals. Nat Genet 2001;27:361-5. 